\title{
Interferon dimers: IFN-PEG-IFN
}

Annabelle Herrington-Symes ${ }^{1}$, Ji-won $\mathrm{Choi}^{1}$ and Steve Brocchini ${ }^{2^{*}}$

\footnotetext{
${ }^{1}$ Abzena, Babraham Research Campus, Babraham, Cambridge CB22 3AT, UK

${ }^{2} \mathrm{UCL}$ School of Pharmacy, London, WC1N 1AX, UK
}

Keywords: Site-specific conjugation, protein-dimer, interferon

Corresponding Author: steve.brocchini@ucl.ac.uk 


\begin{abstract}
Increasingly complex proteins can be made by a recombinant-chemical approach where proteins that can be made easily can be combined by site-specific chemical conjugation to form multifunctional or more active protein therapeutics. Protein dimers may display increased avidity for cell surface receptors. The increased size of protein dimers may also increase circulation times. Cytokines bind to cell surface receptors that dimerise, so much of the solvent accessible surface of a cytokine is involved in binding to its target. Interferon (IFN) homo-dimers (IFN-PEG-IFN) were prepared by two methods: site-specific bis-alkylation conjugation of PEG to the two thiols of a native disulfide or to two imidazoles on a histidine tag of two $\mathrm{His}_{8}$-tagged IFN ( $\left.\mathrm{His}_{8} \mathrm{IFN}\right)$. Several control conjugates were also prepared to assess the relative activity of these IFN homo-dimers. The His $\mathrm{IFN}_{8}-\mathrm{PEG}_{20}-\mathrm{His_{8 }} \mathrm{IFN}$ obtained by histidinespecific conjugation displayed marginally greater in vitro antiviral activity compared to the IFN-PEG ${ }_{20}$-IFN homo-dimer obtained by disulfide re-bridging conjugation. This result is consistent with previous observations in which enhanced retention of activity was made possible by conjugation to an N-terminal His-tag on the IFN. Comparison of the antiviral and antiproliferative activities of the two IFN homo-dimers prepared by disulfide re-bridging conjugation indicated that IFN-PEG ${ }_{10}$-IFN was more biologically active than IFN-PEG ${ }_{20}-\mathrm{IFN}$. This result suggests that the size of PEG may influence the antiviral activity of IFN-PEG-IFN homo-dimers.
\end{abstract}




\section{Introduction}

As therapeutic proteins become more complex there is an opportunity to consider approaches that utilize site-specific conjugation technologies to link proteins that are easily made. Such a hybrid recombinant-chemical approach could in principle be used in a modular way to make a wide range of multifunctional proteins that would not be practical and cost-effective to make by recombinant technologies alone, especially in the early stage of development. An exclusively recombinant approach to make multifunctional therapeutic proteins requires that a polypeptide sequence must be used to link the two or more proteins together. As a non-natural sequence, the linking region may be immunogenic, so polypeptide linkers must be both functional and non-antigenic. As proteins become more complex, there is also often an increased propensity for aggregation and degradation during manufacture and storage $^{1-2}$.

Many proteins are structurally and functionally complex and form dimers ${ }^{3}$. Interferon (IFN) is a cytokine that was first described as an antiviral agent ${ }^{4}$. Type 1 IFNs act on a target cell (not the virus) to inhibit replication and the lifecycle of a wide variety of viruses, thus conferring a state of resistance within the cell to viral infection $^{5}$. There are a number of pharmaceutical forms of Type I IFNs, namely Infergen ${ }^{\circledR}$, Intron $A^{\circledR}$, PegIntron ${ }^{\circledR}$ and Pegasys ${ }^{\circledR}$ for the treatment of viral diseases such as Hepatitis $B$ and Hepatitis $C^{6}$. IFN $a-2 b$ in the presence of zinc forms dimers that have been found to have similar crystal structures to interleukin-10 and IFN- $\gamma$, which interact with their receptors in the dimer form ${ }^{7-8}$.

Site-specific protein modification technologies are required to link proteins together in a hybrid recombinant-chemical approach ${ }^{9-12}$ to make multifunctional proteins. There may be many therapeutic opportunities for multifunctional proteins ${ }^{2}$, ${ }^{13-15}$. Proteins linked together to be multivalent (for example, ${ }^{16}$ ) or dimeric ${ }^{17-19}$ have been described using a range of modification technologies. Dimerised proteins may increase avidity while also increasing solution size to prolong circulation times ${ }^{12}, 20$. Recombinant ${ }^{21}$ and chemical ${ }^{22-23}$ methods have been used to make different cytokine dimers ${ }^{2}$.

Disulfide re-bridging conjugation is a site-specific method for protein modification that exploits the reactivity of the two thiols found in a native disulfide (Figure $1 \mathrm{~A})^{24-25}$. Mechanistically conjugation occurs by bis-alkylation by a sequence of addition-elimination reactions (Figure 1B). Interferon $\alpha 2$ has two disulfides, either of which can be readily conjugated (Figure 2).

\section{FIGURES 1-2}


Disulfide re-bridging conjugation has also been used with reagents functionalized at each terminus of a PEG linker (e.g. PEG di(bis-sulfone) $\underline{\mathbf{4}}$, Figure $3 \mathrm{~B}$ ) to make bivalent IgG antibody mimetics called Fab-PEG-Fab (FpFs) ${ }^{26}$. FpFs are about the same size in solution as an IgG and can be made to be more stable in the hinge region. FpFs have been shown to be biologically active in vitro and in vivo with binding affinities comparable to IgGs targeted to the same epitopes ${ }^{27}$. Interestingly, FpFs display a propensity to have slower dissociation rates once bound to their target. Exploiting reduced dissociation rates may be a strategy to increase efficacy by retaining a therapeutic agent for a longer period of time within a target tissue ${ }^{28-29}$.

Fc-fusion mimetics known as receptor-PEG-receptor (RpR) have also been prepared $^{30}$. It was found that for an RpR targeted to vascular endothelial growth factor, that the RpR displayed a higher rate of association as well as a slower rate of disassociation. Together, these properties showed that a recombinant-chemical fusion protein mimetic can have higher affinity than a recombinant protein targeting the same epitope.

IFN binds to two cell surface receptors that then dimerise, so much of the solvent accessible surface of IFN is involved in binding ${ }^{31}$. Histidines are generally rare in proteins and contiguous histidines are only generally present in His-tags, which are widely used to simplify protein purification. In an effort to avoid modifying the IFN near a residue that may be involved in binding, IFN was made with an 8Histidine tag ( $\mathrm{His}_{8}$-tag) at its $\mathrm{N}$-terminus and then site-specifically mono- and diPEGylated by bis-alkylation using the PEG mono-sulfone $\underline{\mathbf{3}}$ (Figure $3 \mathrm{C}$ ) ${ }^{32}$. His-tag conjugation is thought to occur by a similar addition-elimination reaction (Figure 3D) that occurs with the two thiols from a disulfide bond.

Following a recombinant-chemical approach to make IFN- $\alpha 2$ homo-dimers, activity of the IFN homo-dimer was determined. The cytokine was prepared recombinantly with an $\mathrm{His}_{8}$-tag at its $\mathrm{N}$-terminal (His ${ }_{8} \mathrm{IFN}$ ). PEG-di(mono-sulfone) $\underline{\mathbf{5}}$ (Figure 3B) was then used to make an IFN homo-dimer by histidine-specific conjugation ( $\mathrm{His}_{8} \mathrm{IFN}-\mathrm{PEG}-\mathrm{His}_{8} \mathrm{IFN}$ ). $\mathrm{His}_{8} \mathrm{IFN}$ was also used to make IFN-PEG-IFN by disulfide re-bridging conjugation using PEG di(bis)sulfone $\underline{4}$. Disulfide conjugation on $\mathrm{His}_{8}$ IFN had not been conducted before this study. Mono-PEGylated and diPEGylated conjugates were also prepared as controls for comparison. PEG steric shielding should be at a maximum in the diPEGylated species (Figure 2) and the extent of PEG shielding was probed using a low molecular weight PEG (5 kDa) to make mono- and di-PEGylated IFN conjugates by disulfide re-bridging conjugation. 


\section{Materials and methods}

\section{Preparation of PEG conjugation reagents}

PEG bis-sulfone reagents 1 were prepared as previously described ${ }^{25}$ using commercially available methoxy-terminated PEG mono-amine precursors of 5,10 and $20 \mathrm{kDa}$ molecular weights. The PEG di-(bis-sulfone) reagents were prepared as previously described ${ }^{26}$ and further purified by HPLC. Incubation of the PEG bissulfone precursors ( 1 and 4 ) for $8 \mathrm{~h}\left(37^{\circ} \mathrm{C}\right)$ in $50 \mathrm{mM}$ sodium phosphate buffer $\mathrm{pH} 7.4$ containing $150 \mathrm{mM}$ sodium chloride provided PEG mono-sulfone $\underline{\mathbf{3}}$ and PEG di(mono-sulfone) $\underline{\mathbf{5}}$ for histidine-specific conjugation.

\section{His $_{8}$ IFN production}

The IFN $\alpha-2 a$ (IFN) gene was designed to include eight histidines $\left(\mathrm{His}_{8}\right)$ at the $\mathrm{N}$ terminus $^{32}$. The DNA sequence was optimized using Gene Perfect software (Gene Oracle, Mountain View, California) and further optimized by manual removal of rare codons and repetitive sequences to remove double-strand RNA secondary structure. The Shuffle ${ }^{\mathrm{TM}} \mathrm{T} 7$ Express $E$. coli bacterial strain with inserted plasmids containing the gene for the expression His ${ }_{8}$ IFN. After fermentation and lysis, His ${ }_{8}$ IFN was purified by immobilized metal affinity chromatography (IMAC) followed by fraction pooling and up purification by an anion exchange chromatography (AIEC, HiPrep ${ }^{\text {TM }} \mathrm{Q}$ FF $16 / 60$ column). Following SDS-PAGE analysis, the fractions containing pure $\mathrm{His}_{8} \mathrm{IFN}$ were pooled and the concentration measured by UV absorbance at $280 \mathrm{~nm}$ ( $\varepsilon=0.914,0.9 \mathrm{mg} / \mathrm{mL}, 70 \mathrm{~mL}$ ). The concentration was made to $0.5 \mathrm{mg} / \mathrm{mL}$ and the solution supplemented with $100 \mathrm{mM}$ sodium chloride, $10 \%$ glycerol, protease inhibitor (dilution 1/5000), $1 \mathrm{mM}$ EDTA and $1 \mathrm{mM}$ sodium azide. His $\mathrm{IFN}$ was then aliquoted into $5 \mathrm{~mL}$ cryovials and snap-frozen in liquid nitrogen and stored at $-80^{\circ} \mathrm{C}$.

\section{SDS-PAGE}

SDS-PAGE was conducted using 4-12\% Bis-Tris polyacrylamide gels (NuPAGE ${ }^{\circledR}$; NP0323BOX). Every gel was loaded with Novex ${ }^{\circledR}$ Sharp pre-stained standards (Novex; P/N 57318) and samples were loaded using an appropriately diluted $4 \times$ SDS sample buffer (NuPAGE ${ }^{\circledR}$; NP0007). Gels were run in Xcell SureLock ${ }^{\mathrm{TM}}$ gel electrophoresis tanks (Invitrogen; EI0001) and run in MES SDS-PAGE running buffer $(\times 20)$ from NuPAGE ${ }^{\circledR}\left(\right.$ NP0002-02). Gels were stained using InstantBlue $^{\text {TM }}$ gel stain (Expedeon; ISB01L) and PEG stain (barium chloride and $0.05 \mathrm{M}$ iodide were both from Fisher Scientific (B/0500/53; J/4410/15). Alternatively, silver stain (SilverXpress ${ }^{\circledR}$ Silver staining kit) was used from Invitrogen (LC6100). Densimetric 
analysis was conducted using ImageQuant ${ }^{\text {TM }}$ LAS 4010 instrument (GE Healthcare, 28-9558-10).

\section{Determination of protein concentration}

MicroBCA ${ }^{\mathrm{TM}}$ Protein Assay Kit (Thermo Scientific, 23235) containing a solution of albumin standard $(2 \mathrm{mg} / \mathrm{mL}$ ) was diluted in an appropriate buffer (dependent on the sample buffer) to $200 \mu \mathrm{g} / \mathrm{mL}, 50 \mu \mathrm{g} / \mathrm{mL}, 25 \mu \mathrm{g} / \mathrm{mL}, 12.5 \mu \mathrm{g} / \mathrm{mL}, 6.25 \mu \mathrm{g} / \mathrm{mL}, 3.125$ $\mu \mathrm{g} / \mathrm{mL}$ and $0 \mu \mathrm{g} / \mathrm{mL}$ (blank). The samples $(75-150 \mu \mathrm{L})$ were incubated respectively with $75-150 \mu \mathrm{L}$ MicroBCA $^{\mathrm{TM}}$ solution (prepared by mixing solutions $A: B: C$ in the ration of $25: 24: 1)$ at $37^{\circ} \mathrm{C}$ for $2 \mathrm{~h}$. The absorbance was then measured $(570 \mathrm{~nm}$ ) to generate a standard curve. For $\mathrm{His}_{8} \mathrm{IFN}$ samples, appropriate dilutions $(40-60 \mu \mathrm{g} / \mathrm{mL})$ were made to a concentration within the linear part of the standard curve and the above steps followed. Additionally, for quantification of proteins in small volumes (<900 $\mu \mathrm{L}$ ), Nanodrop 2000 spectrophotometer from Thermo Scientific (SPR-700310L) was used.

\section{Disulfide re-bridging conjugation; preparation of PEG-IFN-PEG, PEG ${ }_{2}$ IFN and PEG-IFN}

$\mathrm{His}_{8} \mathrm{IFN}(5 \mathrm{mg} ; 4.875 \mathrm{~mL}$ ) in $50 \mathrm{mM}$ sodium phosphate, $20 \mathrm{mM}$ EDTA, pH 7.8 was reduced using DTT (1 M, $15.4 \mathrm{mg}, 125 \mu \mathrm{L})$ for $30 \mathrm{~min}$ at RT, and the DTT was removed by buffer exchange using two pre-equilibrated PD-10 columns. The His 8 IFN concentration was quantified using UV at absorbance $280 \mathrm{~nm}(0.797 \mathrm{mg} / \mathrm{mL}, 6.5 \mathrm{~mL})$ and was diluted to $0.5 \mathrm{mg} / \mathrm{mL}(10 \mathrm{~mL})$. $\mathrm{PEG}_{20}$ bis-sulfone 1 was weighed $(5.9 \mathrm{mg}$, 1.2 eq.) and added to the reduced $\mathrm{His}_{8} \mathrm{IFN}(250 \mu \mathrm{L})$ in a $1: 1$ ratio $\left(\mathrm{PEG}_{20}\right.$ bis-sulfone 1:IFN). The $P E_{20}$ IFN reaction mixture was left for $3 \mathrm{~h}$ at $\mathrm{RT}$, then $1 \mathrm{mM}$ glutathione re-oxidising solution (GRS; $50 \mu \mathrm{L}$ of $50 \mathrm{mM} \mathrm{GSH:50} \mathrm{mM} \mathrm{GSSG} \mathrm{in} 50 \mathrm{mM}$ sodium acetate, $\mathrm{pH} 4.0$ ) was added, and the reaction allowed to proceed for a further $16 \mathrm{~h}$ at $20^{\circ} \mathrm{C}$. SDS-PAGE analysis was conducted on the reaction mixture prior to cation exchange (IEX) purification using a $5 \mathrm{~mL}$ HiTrap Macrocap SP column connected to an ÄKTA prime which had been pre-equilibrated with buffer A (100 mM sodium acetate, $\mathrm{pH}$ 4.0). The protein conjugates were eluted with a step gradient of buffer $\mathrm{B}$ (1.0 $\mathrm{M}$ sodium chloride in $100 \mathrm{mM}$ sodium acetate, $\mathrm{pH} 4.0$ ) where the reaction mixture was loaded manually onto the column (ca. $10 \mathrm{~mL}$ ), and the system was washed for $30 \mathrm{~mL}$, then the gradient was initiated. Fractions containing the desired conjugates were combined and centrifugally concentrated using a VivaSpin column with $10,000 \mathrm{MWCO}$ at $3000 \times \mathrm{g}, 4^{\circ} \mathrm{C}$ until ca. $1.5 \mathrm{~mL}$ remained. Once concentrated, the $\mathrm{PEG}_{20}$-IFN and $\mathrm{PEG}_{20}$-IFN-PEG 20 conjugates were buffer exchanged into $50 \mathrm{mM}$ sodium phosphate containing $20 \mathrm{mM}$ EDTA, $\mathrm{pH}$ 7.8. Protein concentration was 
estimated by measuring UV absorbance at $280 \mathrm{~nm}$ and was confirmed by MicroBCA assay for both $\mathrm{PEG}_{20} \mathrm{IFN}$ and $\left(\mathrm{PEG}_{20}\right)_{2}$-IFN conjugates $(330 \mu \mathrm{g} / \mathrm{mL}$ and 147.5 $\mu \mathrm{g} / \mathrm{mL}$, respectively). The yield for both $P E G_{20}-I F N$ and $P E G_{20}-I F N-P E G_{20}$ conjugates was $28.8 \%$ and $12 \%$, respectively. $P E G_{10}-I F N$ and $P E G_{10}-I F N-P E G_{10}$ were prepared similarly in yields of $14 \%$ and $16 \%$, respectively. $\mathrm{PEG}_{5}$-IFN and $\mathrm{PEG}_{5}-\mathrm{IFN}-\mathrm{PEG}_{5}$ were also prepared with yields of $29 \%$ and $34.5 \%$, respectively.

\section{Preparation of $\mathrm{PEG}_{20}-\mathrm{His}_{8} I \mathrm{FN}$ and $\left(\mathrm{PEG}_{20}\right)_{2}-\mathrm{Hi} \mathrm{s}_{8} I \mathrm{FN}$}

$\mathrm{PEG}_{20}$ mono-sulfone $\underline{3}$ ( $0.502 \mathrm{~mL}, 2.5$ eq.) was added to the $\mathrm{His}_{8} \mathrm{IFN}$ solution (2.837 $\mathrm{mL}$ at $1.41 \mathrm{mg} / \mathrm{mL}$ ) and incubated at $20^{\circ} \mathrm{C}$ for $16 \mathrm{~h}$. The reaction mixture was cooled to $4^{\circ} \mathrm{C}$ and then incubated with sodium triacetoxyborohydride $(50 \mathrm{mM})$ dissolved in DMSO at $4^{\circ} \mathrm{C}$ for $1.5 \mathrm{~h}$. The crude mixture $(2 \times 2.5 \mathrm{~mL})$ was buffer exchanged into 100 $\mathrm{mM}$ sodium acetate, $\mathrm{pH} 4.0$, using a pre-equilibrated PD-10 desalting column. The reaction mixture was loaded into a $5 \mathrm{~mL}$ HiTrap Macrocap SP cation exchange column (CIEC, GE Healthcare; 28-9508-59) using an ÄKTA prime plus fitted with a 5 $\mathrm{mL}$ loop which had been pre-equilibrated with buffer $\mathrm{A}(100 \mathrm{mM}$ sodium acetate, $\mathrm{pH}$ 4.0). The His $\mathrm{HFN}_{8}$ species were eluted using a step gradient of buffer $B$ (1.0 M sodium chloride in $100 \mathrm{mM}$ sodium acetate, $\mathrm{pH} 4.0$ ) with the following steps of $27 \%$, $36 \%, 55 \%$ and $100 \%$, with each step eluting over six column volumes. Fractions (2 $\mathrm{mL}$ ) collected over the step gradient were then analyzed by SDS-PAGE and the desired conjugates were combined and concentrated using a VivaSpin column with $10,000 \mathrm{MWCO}$ at $3000 \times \mathrm{g}, 4^{\circ} \mathrm{C}$, until the volume was approximately $1.5 \mathrm{~mL}$. The $\mathrm{PEG}_{20}-\mathrm{His} 8 \mathrm{IFN}$ and $\left(\mathrm{PEG}_{20}\right)_{2}-\mathrm{His}_{8} \mathrm{IFN}$ conjugates were buffer exchanged into buffer $\mathrm{A}$ to decrease the salt concentration and enable the conjugates to bind to the column for a second CIEC purification cycle. Protein concentration and yield was determined by measuring UV absorbance at $280 \mathrm{~nm}$ for both $\mathrm{PEG}_{20}-\mathrm{His}{ }_{8} \mathrm{IFN}$ and $\left(\mathrm{PEG}_{20}\right)_{2}-\mathrm{His}_{8} \mathrm{IFN}$ conjugates $1.054 \mathrm{mg}(26 \%)$ and $0.483 \mathrm{mg}(12 \%)$, respectively. UV absorbance at $280 \mathrm{~nm}$ and MicroBCA ${ }^{\mathrm{TM}}$ assay were conducted to quantify protein concentration after the second purification cycle and the final yields of $\mathrm{PEG}_{20}-\mathrm{His} \mathrm{I}_{8} \mathrm{FN}$ and $\left(\mathrm{PEG}_{20}\right)_{2}-\mathrm{His}_{8} \mathrm{IFN}$ conjugates were $0.7 \mathrm{mg}(17.6 \%)$ and $0.29 \mathrm{mg}(7.13 \%)$, respectively.

\section{Preparation of IFN dimer, His IFN-PEG $_{20}-$ His $_{8}$ IFN by HIS-tag conjugation}

$\mathrm{PEG}_{20}$ di(mono)sulfone $\underline{\mathbf{5}}$ ( $0.515 \mathrm{~mL}, 1$ eq.) was added to His $8 \mathrm{FN}$ solution $(0.5 \mathrm{~mL}$ at $3 \mathrm{mg} / \mathrm{mL}$ ) and incubated for $16 \mathrm{~h}$ at $20^{\circ} \mathrm{C}$. The reaction mixture was cooled to $4^{\circ} \mathrm{C}$ and then incubated with sodium triacetoxyborohydride $(100 \mathrm{mM})$ dissolved in DMSO at $4^{\circ} \mathrm{C}$ for $1.5 \mathrm{~h}$. The crude mixture was then buffer exchanged into $100 \mathrm{mM}$ sodium acetate, $\mathrm{pH} 4.0$, using a pre-equilibrated PD-10 desalting column. The reaction 
mixture was then loaded into a $5 \mathrm{~mL}$ HiTrap Macrocap SP CIEC column using an ÄKTA prime plus fitted with a $5 \mathrm{~mL}$ loop which had been pre-equilibrated with buffer A (100 mM sodium acetate, $\mathrm{pH}$ 4.0). A buffer B (1 M sodium chloride, $100 \mathrm{mM}$ sodium acetate, $\mathrm{pH} 4.0$ ) step gradient of $27 \%, 36 \%, 55 \%, 80 \%$ and $100 \%$ was used to elute the different $\mathrm{His}_{8} \mathrm{IFN}$ species. Fractions containing $\mathrm{His}_{8} \mathrm{IFN}-\mathrm{PEG}_{20}-\mathrm{His}_{8} \mathrm{IFN}$ were combined and concentrated using a VivaSpin column with 10,000 MWCO at $3000 \times g, 4^{\circ} \mathrm{C}$, until the volume was approximately $1.5 \mathrm{~mL}$. The conjugate solution was buffer exchanged into $50 \mathrm{mM}$ sodium phosphate containing $150 \mathrm{mM}$ sodium chloride, $\mathrm{pH} 7.4$ and the protein concentration and yield was measured by UV at $280 \mathrm{~nm}$ for $\mathrm{His}_{8} \mathrm{IFN}-\mathrm{PEG}_{20}-\mathrm{His} \mathrm{s}_{8} \mathrm{IFN}$ to be $0.407 \mathrm{mg} / \mathrm{mL}(13.5 \%)$ yield. SEC was used to separate $\mathrm{His}_{8}$ IFN-PEG ${ }_{20}-\mathrm{His}_{8}$ IFN from trace amount of unmodified His ${ }_{8}$ IFN. The mixture was loaded into a $120 \mathrm{~mL}$ Superdex $^{\mathrm{TM}} 200$ prep grade column 16/60 using an ÄKTA prime plus fitted with a $2 \mathrm{~mL}$ loop which had been pre-equilibrated with $50 \mathrm{mM}$ sodium phosphate containing $150 \mathrm{mM}$ sodium chloride, $\mathrm{pH}$ 7.4. Collected fractions were analyzed by SDS-PAGE and visualized with silver stain, and the purest fractions of His ${ }_{8}$ IFN-PEG ${ }_{20}$-His ${ }_{8}$ IFN were combined and concentrated using pre-equilibrated VivaSpin column with $10,000 \mathrm{MWCO}$ at $3000 \times \mathrm{g}, 4^{\circ} \mathrm{C}$, until approximately $1.5 \mathrm{~mL}$ remained. The $\mathrm{His}_{8} \mathrm{IFN}-\mathrm{PEG}_{20}-\mathrm{His} \mathrm{s}_{8} \mathrm{IFN}$ concentration and yield $(0.030 \mathrm{mg} / \mathrm{mL}, 1.5 \%)$ was measured by UV at $280 \mathrm{~nm}$ and MicroBCA assay.

\section{Preparation of IFN dimer, IFN-PEG-IFN by disulfide re-bridging conjugation}

$\mathrm{His}_{8} \mathrm{IFN}(2 \mathrm{mg} / \mathrm{mL}, 5 \mathrm{~mL})$ in $50 \mathrm{mM}$ sodium phosphate $20 \mathrm{mM}$ EDTA, pH 7.8, was reduced using DTT $(1 \mathrm{M}, 15.4 \mathrm{mg}, 125 \mu \mathrm{L})$ for $30 \mathrm{~min}$ at $\mathrm{RT}$, and the DTT was removed by buffer exchange using three pre-equilibrated PD-10 columns. Protein concentration was quantified by UV at $280 \mathrm{~nm}(0.752 \mathrm{mg} / \mathrm{mL}, 11 \mathrm{~mL})$ and $\mathrm{His}_{8} \mathrm{IFN}$ was diluted to $0.5 \mathrm{mg} / \mathrm{mL}(15 \mathrm{~mL})$, where one half $(7.5 \mathrm{~mL}, 4.1 \mathrm{mg})$ of this reduced $\mathrm{His}_{8}$ IFN was used to prepare IFN-PEG 10 IFN and the other half used to prepare IFN$\mathrm{PEG}_{20}$-IFN. For IFN-PEG ${ }_{20}$-IFN, $\mathrm{PEG}_{20}$ di(bis)sulfone 4 (2.5 mg) was added to the solution of reduced $\mathrm{His}_{8} \mathrm{IFN}(106 \mu \mathrm{L})$ in a $2: 1$ ratio $\left(\mathrm{PEG}_{20}\right.$ di(bis)sulfone 4 :IFN). The reaction mixture was left for $5 \mathrm{~h}$ at $20^{\circ} \mathrm{C}$, then GRS $(1 \mathrm{mM}, 153.1 \mu \mathrm{L}$ of $50 \mathrm{mM}$ GSH:50 mM GSSG in $50 \mathrm{mM}$ sodium acetate, $\mathrm{pH} 4.0$ ) was added, and the reaction was allowed to proceed for a further $16 \mathrm{~h}$ at $20^{\circ} \mathrm{C}$. SDS-PAGE analysis was conducted on the reaction mixture prior to and after GRS addition. The IFN-PEG ${ }_{20}-$ IFN conjugate was then incubated with sodium triacetoxyborohydride (100 mM dissolved in DMSO) at $4^{\circ} \mathrm{C}$ for $1.5 \mathrm{~h}$. The reaction mixture $(7.5 \mathrm{~mL})$ was then buffer exchanged into $100 \mathrm{mM}$ sodium acetate, $\mathrm{pH}$ 4.0, using three pre-equilibrated PD-10 desalting columns. CIEC purification was conducted with a $5 \mathrm{~mL}$ Macrocap SP ion 
exchange column using an ÄKTA Prime Plus fitted with two $5 \mathrm{~mL}$ loops which had been pre-equilibrated with buffer $\mathrm{A}(100 \mathrm{mM}$ sodium acetate, $\mathrm{pH} 4.0)$. The protein conjugates were eluted with a step gradient of buffer B: $1.0 \mathrm{M}$ sodium chloride in 100 $\mathrm{mM}$ sodium acetate, $\mathrm{pH} 4.0$, of $45 \%, 55 \%$ and $100 \%$.

IFN-PEG ${ }_{10}$ IFN and $\mathrm{His}_{8}$ IFN mixtures were separately combined and concentrated using a VivaSpin column with $10,000 \mathrm{MWCO}$ at $3000 \times \mathrm{g}, 4^{\circ} \mathrm{C}$ until approximately $1.5 \mathrm{~mL}$ remained. The mixtures were buffer exchanged using preequilibrated NAP-10 columns into $50 \mathrm{mM}$ sodium phosphate containing $150 \mathrm{mM}$ sodium chloride, $\mathrm{pH}$ 7.8. Protein concentration and yield was calculated by measuring UV at $280 \mathrm{~nm}$ for both IFN-PEG ${ }_{20}$ IFN + His 8 IFN, IFN-PEG ${ }_{10}$ IFN + $\mathrm{His}_{8} \mathrm{IFN}$ mixtures $(0.682 \mathrm{mg} / \mathrm{mL}, 27.3 \%$ and $1.12 \mathrm{mg} / \mathrm{mL}, 27.3 \%$, respectively).

SEC purification of IFN-PEG 20 IFN + His 8 IFN and IFN-PEG ${ }_{10}-\mathrm{IFN}+\mathrm{His}_{8} I F N$ mixtures was performed to separate $\mathrm{His}_{8} \mathrm{IFN}$ from IFN-PEG $0_{20}$ IFN and IFN-PEG ${ }_{10}$ IFN. The mixtures were loaded separately onto the Superdex 200 Prep Grade Column 16/60 $120 \mathrm{~mL}$ column, which had been pre-equilibrated with $50 \mathrm{mM}$ sodium phosphate containing 20 mM EDTA, pH 7.8, using an ÄKTA Prime Plus fitted with a $2 \mathrm{~mL}$ loop. The protein conjugates were eluted over $120 \mathrm{~mL}$ and the fractions collected were then analyzed by SDS-PAGE and stained using silver stain. Fractions were combined and concentrated using a VivaSpin column with 10,000 MWCO at $3000 \times g, 4^{\circ} \mathrm{C}$ until approximately $1.5 \mathrm{~mL}$ remained. Protein concentration for both IFN-PEG 20 -IFN and IFN-PEG ${ }_{10}$ IFN were measured by UV at $280 \mathrm{~nm}$ and confirmed by MicroBCA assay to 0.035 and $0.046 \mathrm{mg} / \mathrm{mL}$, respectively. Final yields for IFN$\mathrm{PEG}_{20}$-IFN and IFN-PEG $10^{-}$IFN conjugates were $1.4 \%$ and $1.12 \%$, respectively.

\section{Assessment of conjugate stability}

Samples were incubated at $4^{\circ} \mathrm{C}$ for 7 days and monitored by SDS-PAGE with the resulting gels stained by InstantBlue ${ }^{\mathrm{TM}}$ and $\mathrm{PEG}$ stain. For conjugated proteins with a low concentration, silver stain was used to detect the conjugate and any free protein. Accelerated stability assessments were conducted by first buffer exchanging samples into $10 \mathrm{mM}$ ammonium bicarbonate, $\mathrm{pH} 8.0$, and protein concentrations were diluted to $50 \mu \mathrm{g} / \mathrm{mL}$, and then $27 \mu \mathrm{L}$ was transferred into $4 \times 0.5 \mathrm{~mL}$ sample vials. For each protein product, two of the sample vials were made up to $30 \mu \mathrm{L}$ with the addition of $3 \mu \mathrm{L}$ of $10 \mathrm{mM}$ ammonium bicarbonate, $\mathrm{pH} 8.0$, while the two remaining sample vials are made up to $30 \mu \mathrm{L}$ with $100 \mathrm{mM}$ DTT solution. For each protein product, two sample vials (one with DTT and one without) were heated on a metal heating block to $90^{\circ} \mathrm{C}$ for $10 \mathrm{~min}$. The two remaining sample vials (one with DTT and one without) were then heated in the metal heating block for $1 \mathrm{~h}$ at $50^{\circ} \mathrm{C}$. 
Once all sample vials for each protein product were cooled to RT, $22 \mu \mathrm{L}$ was removed from each sample vial and transferred into new labeled sample vials containing loading dye $(11 \mu \mathrm{L})$. The sample/loading dye mixtures were subsequently analyzed by SDS-PAGE and stained with InstantBlue ${ }^{\mathrm{TM}}$ and PEG stain, to identify if the protein conjugates underwent de-conjugation as determined by the presence of unmodified $\mathrm{His}_{8}$ IFN.

\section{Antiviral potency assay}

The human lung fibroblast A549 cell line (HPACC; 86012804) was maintained in Dulbecco's Modified Eagles medium (DMEM) (Gibco/Fisher Scientific; VX21969035) supplemented with 10\% Fetal Bovine Serum (FBS) (Gibco/Fisher Scientific; VX25030024), 50 units/mL penicillin (PAA; P11-101), 2 mM L-glutamine (Sigma; G7513-100 mL) and $50 \mathrm{\mu g} / \mathrm{mL}$ streptomycin. A549 cells were infected using encephalomyocarditis virus (EMCV) (ATCC; VR-129B). Sample controls were NIBSC IFN standard (HPACC; 95/650) and Pegasys ${ }^{\circledR}$ (Roche). Phosphate buffered saline (PBS), pH 7.4 (BPE399-20); formaldehyde (40\%) (F/145/PB17) and SDS (10\%) (BPE 2436-1) were supplied from Fisher Scientific. Methyl violet 2B was from Sigma Aldrich (198099). Microplate reader was supplied from Dynex Technologies/Opsys MR and the microplate shaker was supplied from VWR (444-7094). To conduct the antiviral assay, A549 cells were plated $\left(1.7 \times 10^{5}\right.$ cells $/ \mathrm{mL}$ at $50 \mu \mathrm{L} /$ well $)$ in 96 well flatbottomed tissue culture plates, then incubated at $37^{\circ} \mathrm{C}, 5 \% \mathrm{CO}_{2}$, overnight until the cells were $80 \%$ confluent. Serial dilutions (2-fold) of the IFN samples were prepared in DMEM/10\% FBS in 96 well V-bottom plates and diluted samples $(50 \mu \mathrm{L})$ were transferred to flat-bottom plates and incubated for $24 \mathrm{~h}$ at $37^{\circ} \mathrm{C}, 5 \% \mathrm{CO}_{2}$. Protein samples were tested in triplicate and control wells contained only cells (negative control) or cells with virus (positive control). After incubation, the protein sample and media were discarded and EMCV $(50 \mu \mathrm{L})$, pre-titrated to achieve complete killing in $24 \mathrm{~h}$ in control wells, was added to all wells except for the negative control wells where, $50 \mu \mathrm{L} /$ well of DMEM/2\% FBS was added. The plate was then incubated for $21 \mathrm{~h}$ at $37^{\circ} \mathrm{C}$ after which ca. $80 \%$ cell death occurred in the control wells. Media was then discarded and the wells were washed with $300 \mu \mathrm{L} /$ well of PBS added. Plates were then incubated for $30 \mathrm{~min}$ at RT with $50 \mu \mathrm{L} /$ well of $4 \%$ formaldehyde/ $0.5 \%$ methyl violet. After incubation, the plates were washed twice with PBS $(200 \mu \mathrm{L} /$ well $)$ and tap-dried. Dye was solubilized by 20 min agitation in $50 \mu \mathrm{L} /$ well of $2 \%$ SDS and the absorbance measured at $570 \mathrm{~nm}$.

The interferon concentration (the log reciprocal of the interferon dilution) was plotted against the absorbance achieved and the reduction in cell viability was fitted 
to a sigmoidal dose-response curve. Data was only considered valid under two criteria, i) the variation between the straight part of the sigmoidal curve and the data points was small enough to be accurately represented by a straight line (absolute sum of squares ( $r$ value)) and ii) the $E_{50}$ for the internal control, NIBSC IFN $\alpha$, was within the expected range. If the data achieved was not in line with this criterion, the data were not used. Accepted potency data was then turned into international units (IU) to allow for direct comparisons to be made with data described in the literature. GraphPad Prism 5 was used for all data analysis.

\section{Antiproliferative assay}

The human Negroid Burkitt's lymphoma Daudi cell line (HPACC, 85011437) was maintained in RPMI 1640 media supplemented with 10\% FBS, 50 units $/ \mathrm{mL}$ penicillin and $50 \mu \mathrm{g} / \mathrm{mL}$ streptomycin. Daudi cells were plated $\left(1.7 \times 10^{5}\right.$ cells $/ \mathrm{mL}$ at $100 \mu \mathrm{L} /$ well $)$ in a 96 well round-bottomed tissue culture plates and these were incubated at $37^{\circ} \mathrm{C}$, $5 \% \mathrm{CO}_{2}$. Serial dilutions (three-fold) of IFN a controls (NIBSC IFN and Pegasys ${ }^{\circledR}$ ) were conducted in $1.5 \mathrm{~mL}$ centrifuge tubes using RPMI 1640/10\% FBS. IFN controls were pipetted into the plate $(100 \mu \mathrm{L} /$ well $)$ from low to high dilutions in duplicate, with each well having a final volume of $200 \mu \mathrm{L} /$ well. Control wells contained only media without cells (negative control) or cells with media (as positive control). The plates were incubated for $72 \mathrm{~h}$ at $37^{\circ} \mathrm{C}, 5 \% \mathrm{CO}_{2}$. Methyl thiazolyl tetrazolium (MTT, 5 $\mathrm{mg} / \mathrm{mL}$, Sigma) was dissolved in PBS and was prepared 10 min before addition to the wells. MTT solution was filtered through a $0.2 \mu \mathrm{m}$ syringe filter and then added $(20 \mu \mathrm{L})$ to each well and the plates incubated for $3 \mathrm{~h}$ at $37^{\circ} \mathrm{C}, 5 \% \mathrm{CO}_{2}$. Plates were then centrifuged at $1500 \times \mathrm{g}$ for $10 \mathrm{~min}$, allowing formazan crystals to sediment. Using a multichannel pipette, the supernatant was carefully removed and $100 \mu \mathrm{L} /$ well nonsterile DMSO was added to solubilize the crystals by agitation. Absorbance was then measured at $570 \mathrm{~nm}$. Cell viability (\%) was plotted against control wells using sitespecific binding with Hill slope on a semi-log graph (GraphPad Prism 5). The interferon concentration (the log reciprocal of the interferon dilution) was plotted against the absorbance achieved and the reduction in cell viability was fitted to a sigmoidal dose-response curve. Data was only accepted if the variation between the straight part of the sigmoidal curve and the data points was small enough to be accurately represented by a straight line (absolute sum of squares ( $r$ value)). 


\section{Results and Discussion}

\section{Reagent synthesis.}

Terminally functionalized PEG di(bis-sulfones) $\underline{4}$ (Figure 3B) capable of bis-alkylation conjugation at each PEG terminus were prepared using commercially available 10 and $20 \mathrm{kDa}$ PEG diamines $\left(\mathrm{NH}_{2} \text {-PEG-NH}\right)^{26}$ and the precursor bis-sulfone linker ${ }^{25}$. Likewise the, PEG bis-sulfones 1 were prepared from commercially available 5, 10 and $20 \mathrm{kDa}$ PEG amine ${ }^{25}$. The mono-sulfone adducts ( $\underline{\mathbf{3}}$ and $\underline{\mathbf{5}}$ ) were obtained by elimination of toluene sulfinic acid $\underline{2}^{24}$.

\section{FIGURE 3}

\section{Preparation of His $\mathrm{HIN}_{8}$}

Recombinant IFN $\alpha-2$ a fused with an eight-histidine tag $\left(\mathrm{His}_{8}\right)$ was prepared by using the SHuffle ${ }^{\mathrm{TM}}$ T7 expression system which can correctly produce disulfide containing proteins in high yields within the cytoplasm of E. coli ${ }^{33}$. The His $\mathrm{H}_{8}$-tag was attached between the cysteine and methionine at the $\mathrm{N}$-terminus end of IFN ${ }^{32}$. Lysis was conducted firstly by sonication and then cross flow-filtration to remove the soluble $\mathrm{His}_{8} \mathrm{IFN}$ from the cell debris. As His $\mathrm{IFN}$ was expressed as a soluble protein, purification was conducted at physiological $\mathrm{pH}$ to maintain the stability and activity of the protein. His IFN $_{8}$ was purified in two steps, first using immobilized metal affinity chromatography (IMAC) taking advantage of the presence of the $\mathrm{His}_{8}$-tag. His ${ }_{8}$ IFN was then eluted over an anion exchange column (AIEC).

The identity of pure His IFN (Figure 4A) was confirmed by Western blot (Figure 4B). His ${ }_{8} \mathrm{IFN}$ was prepared two times in $500 \mathrm{~mL}$ cultures with a final yield after purification of between $60-70 \mathrm{mg}$. His $8 \mathrm{FN}$ was stored in small vials at $-80^{\circ} \mathrm{C}$ $(0.5 \mathrm{mg} / \mathrm{mL})$ for conjugation reactions. The biological potency of $\mathrm{His}_{8} \mathrm{IFN}$ was assessed in vitro by the prevention of infection of A549 cells by EMCV ${ }^{34}$. The $\mathrm{His}_{8} \mathrm{IFN}$ displayed a specific activity of $231 \pm 10.95 \mathrm{MIU} / \mathrm{mg}$, whilst the positive control of NIBSC (non-his-tagged) IFN $\alpha-2 a$ displayed an activity of $254 \mathrm{MIU} / \mathrm{mg}$. In literature $\mathrm{His}_{8} \mathrm{IFN}$ has been reported to display an $\mathrm{ED}_{50}$ of $7 \mathrm{pg} / \mathrm{mL}^{32}$. The activity of non-histagged interferon $\alpha 2$ is reported to be $1.4 \times 10^{8} \mathrm{IU} / \mathrm{mg}$.

\section{FIGURE 4}

\section{Preparation of the His ${ }_{8} I F N-P E G_{20}-H i s_{8} I F N$ homo-dimer by histidine-specific conjugation}

The IFN-PEG-IFN homo-dimer ( $\left.\mathrm{His}_{8} \mathrm{IFN}-\mathrm{PEG}_{20}-\mathrm{His}_{8} \mathrm{IFN}\right)$ derived from histidinespecific conjugation was achieved using $\mathrm{PEG}_{20}$ di-(mono-sulfone) $\underline{\mathbf{5}}$ (1 eq. in $200 \mathrm{mM}$ sodium phosphate containing $150 \mathrm{mM}$ sodium chloride) and three molar equivalents 
of $\mathrm{His}_{8} \mathrm{IFN}(3.3 \mathrm{mg} / \mathrm{mL}, 0.5 \mathrm{~mL}$ in $50 \mathrm{mM}$ sodium acetate, $\mathrm{pH} 5.3$, containing $35 \mu \mathrm{M}$ hydroquinone). Histidine-specific conjugation generally requires a slightly acidic $\mathrm{pH}$ to maintain site-selectivity, so use of the mono-sulfone reagents ( $\underline{\mathbf{3}}$ and $\underline{\mathbf{5}}$ ) is one way to better target the $\mathrm{His}_{8}$-tag on the IFN. The reaction mixture was incubated for $16 \mathrm{~h}$ at $20^{\circ} \mathrm{C}$ at approximately $\mathrm{pH} 6.5$ and then treated with $100 \mathrm{mM}$ sodium tri-acetoxyborohydride (STAB) to reduce the electron-withdrawing carbonyl to prevent retroMichael reactions. A band at $70-80 \mathrm{kDa}$ in the SDS-PAGE was consistent for the formation of $\mathrm{His}_{8}$ IFN-PEG ${ }_{20}-\mathrm{His}_{8}$ IFN. The molecular weight of each IFN is ca. $20 \mathrm{kDa}$ $(2 \times 20 \mathrm{kDa}=40 \mathrm{kDa})$ and PEG often migrates in SDS-PAGE to about twice the molecular weight of the protein standards.

However, SDS-PAGE analysis showed that conversion was low with a significant amount of unconjugated IFN still present in the reaction mixture. Since the goal was to isolate the IFN homo-dimer, the reaction mixture was subjected to purification by CIEX. The $\mathrm{His}_{8} \mathrm{IFN}-\mathrm{PEG}_{20}-\mathrm{His}{ }_{8} \mathrm{IFN}$ dimer was separated from the unconjugated PEG species (Figure 5A, lane 3), but the desired $\mathrm{His}_{8} \mathrm{IFN}-\mathrm{PEG}_{20^{-}}$ $\mathrm{His}_{8}$ IFN dimer could not be separated from other high molecular weight IFN impurities even after a second purification by CIEX (Figure $5 \mathrm{~A}$, lane 4 ).

\section{FIGURE 5}

The conjugation was repeated and a single CIEX purification was conducted followed by purification of the fractions containing $\mathrm{His}_{8}$ IFN-PEG ${ }_{20}-\mathrm{His}_{8} \mathrm{IFN}$ by SEC to remove the high molecular weight species (Figure 5A, lane 5). An anti-IFN Western blot was conducted to confirm the presence of IFN (Figure 5A, lane 6 ) in the purified $\mathrm{His}_{8} \mathrm{IFN}-\mathrm{PEG}_{20}-\mathrm{His_{8 }} \mathrm{IFN}$.

The final yield of $\mathrm{His}_{8} \mathrm{IFN}-\mathrm{PEG}_{20}-\mathrm{His}_{8} \mathrm{IFN}$ homo-dimer after one cycle of IEX followed by one cycle of SEC purification was $1.5 \%$ (Table 1) based on UV and MicroBCA ${ }^{\mathrm{TM}}$ assays. $\mathrm{PEG}_{20}-\mathrm{His}_{8} \mathrm{IFN}$ and $\left(\mathrm{PEG}_{20}\right)_{2}-\mathrm{His}_{8} \mathrm{IFN}$ were prepared using the PEG mono-sulfone 3. Good purification of these modified proteins was accomplished using two IEX steps and the purified conjugates were isolated in $17.6 \%(0.7 \mathrm{mg})$ and $7.1 \%(0.29 \mathrm{mg})$ yields, respectively (Figure 5B, Lanes 3-4, Table 1).

\section{TABLE 1}

The purified $\mathrm{His}_{8} \mathrm{IFN}-\mathrm{PEG}_{20}-\mathrm{His_{8 }} \mathrm{IFN}$ was stored at $4^{\circ} \mathrm{C}$ for 2 months $(50 \mathrm{mM}$ sodium phosphate containing $150 \mathrm{mM}$ sodium chloride, $\mathrm{pH}$ 7.8). No free His 8 IFN was observed in the SDS PAGE using silver stain, indicating there was no deconjugation. Conjugate stability for $\mathrm{His}_{8} \mathrm{IFN}-\mathrm{PEG}_{20}-\mathrm{Hi} \mathrm{s}_{8} \mathrm{IFN}$ was also evaluated at $50^{\circ} \mathrm{C}$ and $90^{\circ} \mathrm{C}$ in the presence and absence of DTT (Figure $5 \mathrm{C}$ ). No free His 8 IFN was observed. The imidazole side chain of histidine is a weaker nucleophile than free 
thiol. Since conjugate formation occurs via a reaction mechanism that involves a sequence of equilibria (Figure 3D), it was important to ensure that bonds formed between the $\mathrm{His}_{8}$-tag and the PEG di-(mono-sulfone) $\underline{\mathbf{5}}$ had been stabilized by the treatment with STAB to reduce the electron-withdrawing carbonyl in the reagent after conjugation. Both $\mathrm{PEG}_{20}-\mathrm{His}_{8} \mathrm{IFN}$ and $\left(\mathrm{PEG}_{20}\right)_{2}-\mathrm{His}_{8} \mathrm{IFN}$ conjugates that were also prepared in this study were evaluated at $50^{\circ} \mathrm{C}$ and $90^{\circ} \mathrm{C}$ in the presence and absence of DTT (Figure 5D). No de-conjugation was observed for either of these conjugates.

\section{Preparation of IFN-PEG-IFN homo-dimers by disulfide re-bridging conjugation}

Conjugation of the disulfide thiols has not previously been conducted on $\mathrm{His}_{8} \mathrm{IFN}$. Once the IFN thiols are liberated after disulfide reduction, thiol addition to the PEG bis-sulfone reagents ( 1 and $\underline{\mathbf{4}}$ ) is much more favored compared to the addition reaction of the imidazole side-chain of histidine. IFN has two accessible disulfides and IFN maintains its tertiary structure in the presence of DTT after reduction of the disulfides ${ }^{35}$.

Bis-alkylation conjugation of $\mathrm{His}_{8} \mathrm{IFN}$ was first conducted using PEG bissulfone 1 (5, 10 and $20 \mathrm{kDa}$ ) to prepare the corresponding PEG-IFN and PEG ${ }_{2}$ IFN conjugates (Figure 6A, lanes 3-8, Table 1). These conjugates were isolated from the same reaction mixture using 1 molar equivalent of PEG bis-sulfone 1 to protein, and the $\mathrm{PEG}_{2}$-IFN conjugate was easily isolated as a co-product. The conjugation conversion and the purification process comprising a single CIEX for the His ${ }_{8}$ IFNderived conjugates is similar to what has been observed with $\operatorname{IFN}^{36}$ that does not possess a His-tag.

\section{FIGURE 6}

The IFN-PEG-IFN homo-dimers were prepared using a 2:1 molar ratio of $\mathrm{His}_{8} \mathrm{IFN}$ to PEG di(bis)sulfone $\underline{4}$ (10 and $20 \mathrm{kDa}$ reagents). His ${ }_{8}$ IFN was reduced using $20 \mathrm{mM}$ DTT and then the protein was buffer exchanged into $50 \mathrm{mM}$ sodium phosphate $20 \mathrm{mM}$ EDTA. A pH of 7.8 was used because the PEG di(bis)sulfone 4 readily undergoes elimination of the toluene sulfinic acid 2 (Figure $3 \mathrm{~B}$ ) to generate the PEG di-(mono-sulfone) $\underline{\mathbf{5}}$ in situ followed by the Michael reaction of free protein thiols. Reduced His 8 IFN $(0.5 \mathrm{mg} / \mathrm{mL}, 7.5 \mathrm{~mL})$ was allowed to incubate for $5 \mathrm{~h}$ at $20^{\circ} \mathrm{C}$ separately with the $10 \mathrm{kDa}$ and $20 \mathrm{kDa}$ PEG di(bis-sulfone)s 4 . To re-oxidise the unconjugated thiols of the remaining disulfide, a glutathione re-oxidising solution (GRS) was added ( $50 \mathrm{mM}, 153 \mu \mathrm{L}$ ) and the reaction mixture was allowed to incubate a further $16 \mathrm{~h}$ at $20^{\circ} \mathrm{C}$ before being treated with STAB to reduce the electronwithdrawing carbonyl to prevent retro-Michael reactions. 
Purification of the two IFN-PEG-IFN homo-dimers was accomplished by CIEX followed SEC (Figure 6A, lanes 9 and 10). SEC was required to purify the desired IFN homo-dimer from the starting His IFN which could not be separated by CIEX. Anti-IFN Western blots substantiated the presence of IFN in the homo-dimers while, importantly, confirming the absence of the starting $\mathrm{His}_{8} \mathrm{IFN}$ in the purified products.

UV and BCA quantification was conducted and the yields obtained for the purified IFN-PEG ${ }_{20}$-IFN and IFN-PEG $10^{-I F N}$ were $0.85 \%(35 \mu \mathrm{g} / \mathrm{mL})$ and $1.1 \%(46$ $\mu \mathrm{g} / \mathrm{mL}$ ), respectively. As with the IFN homo-dimer derived from histidine-specific conjugation ( $\mathrm{His}_{8} \mathrm{IFN}-\mathrm{PEG}_{20}-\mathrm{His_{8 }} \mathrm{IFN}$ ), the isolated yields for the purified IFN homodimers were low. Clearly the SEC purification step is not optimal for a purification process, since SEC can result in reduced yields for small scale reactions. The reaction was repeated to make both the 10 and $20 \mathrm{kDa}$ IFN homo-dimers, but the yields were not improved.

Storage of the disulfide re-bridged conjugates in $50 \mathrm{mM}$ sodium phosphate, $150 \mathrm{mM} \mathrm{NaCl}, \mathrm{pH} 7.8$, for 7 days at $4^{\circ} \mathrm{C}$ did not show any evidence of de-conjugation (Figure 6B). Accelerated stability studies were also performed by incubating the IFN homo-dimers and their mono-PEGylated variants (ca. $40 \mu \mathrm{g} / \mathrm{mL})$ at $90^{\circ} \mathrm{C}(10 \mathrm{~min})$ with or without $20 \mathrm{mM}$ DTT (Figure 6C-D). No free His ${ }_{8} \mathrm{IFN}$ was observed indicating that there was no de-conjugation of the IFN from the PEG-linker.

\section{In vitro potency of IFN homodimers}

IFN is a pleiotropic cytokine that has numerous distinct biological properties; one of these is antiviral activity. This can be assessed in vitro, by the prevention of infection of A549 cells by EMCV ${ }^{34}$. The relative activity of the IFN homo-dimers and PEG-IFN conjugates was determined by comparing the dose (concentration) of the sample, which displays $50 \%$ prevention of infection in cells or $\left(50 \%\right.$ effective dose or $\left.\mathrm{ED}_{50}\right)$ in vitro to the dose of the National Institute for Biological Standards and Control (NIBSC) reference standard IFN $\alpha-2 a$. The $E_{50}$ was then used to calculate the specific activity of each $\mathrm{His}_{8}$ IFN conjugate. In addition to the NIBSC IFN control, Pegasys ${ }^{\circledR}$ was also used. Pegasys ${ }^{\circledR}$ is a $40 \mathrm{kDa}$ branched PEG-IFN $\alpha-2$ a conjugate that is a marketed product for the treatment of hepatitis $C$.

The IFN homo-dimers retained activity that was comparable or better than Pegasys ${ }^{\circledR}$ (Figure 7A-B and Table1). Both PEG $_{20}$-derived homo-dimers (His $\mathrm{IFN}$ $\mathrm{PEG}_{20}-\mathrm{His}_{8}$ IFN and IFN-PEG ${ }_{20}$-IFN) displayed less activity than the corresponding mono-PEGylated species, but more activity than the corresponding di-PEGylated species. However, the IFN homo-dimer IFN-PEG ${ }_{10}$-IFN did retain more activity than 
the corresponding $\mathrm{PEG}_{10}$-IFN mono-PEGylated conjugate (Figure 7B, Table 1), suggesting there could be a dependency on PEG size linking the two IFNs.

\section{FIGURE 7}

The histidine-specific mono-PEGylated conjugate $\left(\mathrm{PEG}_{20}-\mathrm{His_{8 }} \mathrm{IFN}\right)$ displayed greater retained activity compared to the disulfide re-bridged mono-PEGylated conjugates, $\mathrm{PEG}_{10}$-IFN and $\mathrm{PEG}_{20}$-IFN (Table 1). This is consistent with a previous study for the PEGylating IFN at the N-terminal His-tag ${ }^{32}$. When comparing the two $\mathrm{PEG}_{20}$-derived homo-dimers, the histidine-specific homo-dimer (His $8 \mathrm{FN}-\mathrm{PEG}_{20^{-}}$ $\mathrm{His}_{8} \mathrm{IFN}$ ) also displayed more activity than the IFN-PEG ${ }_{20}$-IFN dimer.

Due to the site specificity of the disulfide re-bridging PEGylation, the activity of $\mathrm{PEG}_{10}$-IFN and $\mathrm{PEG}_{20}$-IFN were comparable as previously reported ${ }^{24}$. Interestingly, the $\mathrm{PEG}_{5}$-IFN conjugate displayed considerably more activity than any of the higher molecular weight PEG-IFN conjugates (Figure 7 and Table 1), suggesting that when $\mathrm{PEG}_{5}$ is site-specifically conjugated by disulfide re-bridging conjugation, this molecular weight of PEG is below a steric shielding threshold at these sites of conjugation.

An antiproliferative assay using Daudi cells was conducted, but due to the large quantity of sample required, only the disulfide re-bridged mono-PEGylated and IFN homo-dimers were evaluated. As with the antiviral assay, the $\mathrm{PEG}_{10}$ homo-dimer (IFN-PEG $10^{-}$IFN, $1.52 \pm 0.47 \mathrm{MIU} / \mathrm{mg}$ ) again displayed higher activity than the $\mathrm{PEG}_{20}$ homo-dimer (IFN-PEG ${ }_{20}$-IFN, $0.81 \pm 0.09 \mathrm{MIU} / \mathrm{mg}$ ). The activity of the starting $\mathrm{His}_{8} \mathrm{IFN}$ in this assay was $329.36 \pm 87.98 \mathrm{MIU} / \mathrm{mg}$.

\section{Conclusion}

Interferon (IFN) homo-dimers were prepared by site-specific bis-alkylation conjugation of IFN. PEG (10 and $20 \mathrm{kDa}$ ) di-functionalized linkers were used to conjugate two IFN molecules to the two PEG termini. Both histidine-specific and disulfide re-bridging conjugation processes were examined to isolate the purified the IFN homo-dimers. The His IFN-PEG ${ }_{20}-H_{i} s_{8} I F N$ obtained by histidine-specific conjugation displayed marginally greater in vitro antiviral activity than the IFN-PEG ${ }_{20}$ IFN homo-dimer obtained by disulfide re-bridging conjugation. This result is consistent with previous observations in which enhanced retention of activity was made possible by conjugation to an $\mathrm{N}$-terminal His-tag on the IFN. Comparison of the antiviral and antiproliferative activities of the two IFN homo-dimers prepared by disulfide re-bridging conjugation indicated that IFN-PEG ${ }_{10}$-IFN was more biologically 
active than IFN-PEG 20 -IFN. This result suggests that the size of PEG may influence the antiviral activity of IFN-PEG-IFN homo-dimers.

\section{Acknowledgements.}

We are grateful for funding and the donation of reagents from Abzena. AHS is also grateful to Abzena for helping to fund her PhD. 


\section{Figures}

\section{Figure 1}
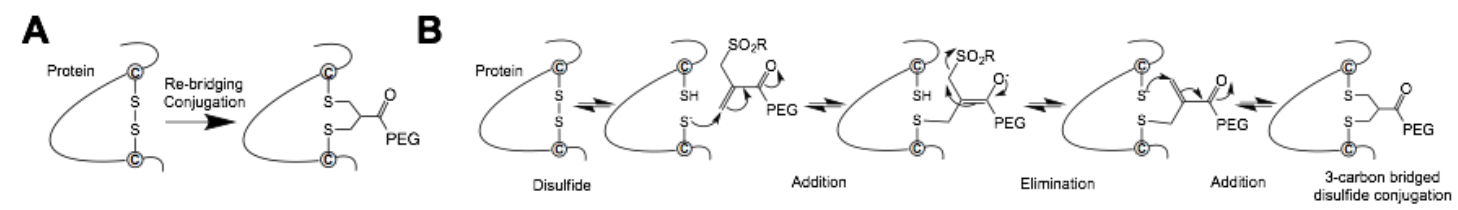

Figure 1. (A) Disulfide re-bridging conjugation is a site-specific strategy for modifying proteins by bis-alkylation where a native disulfide is linked with a three-carbon bridge that is bound to PEG. (B) Bis-alkylation conjugation occurs by a sequence of addition and elimination steps resulting in the formation of a three-carbon bridge.

\section{Figure 2}

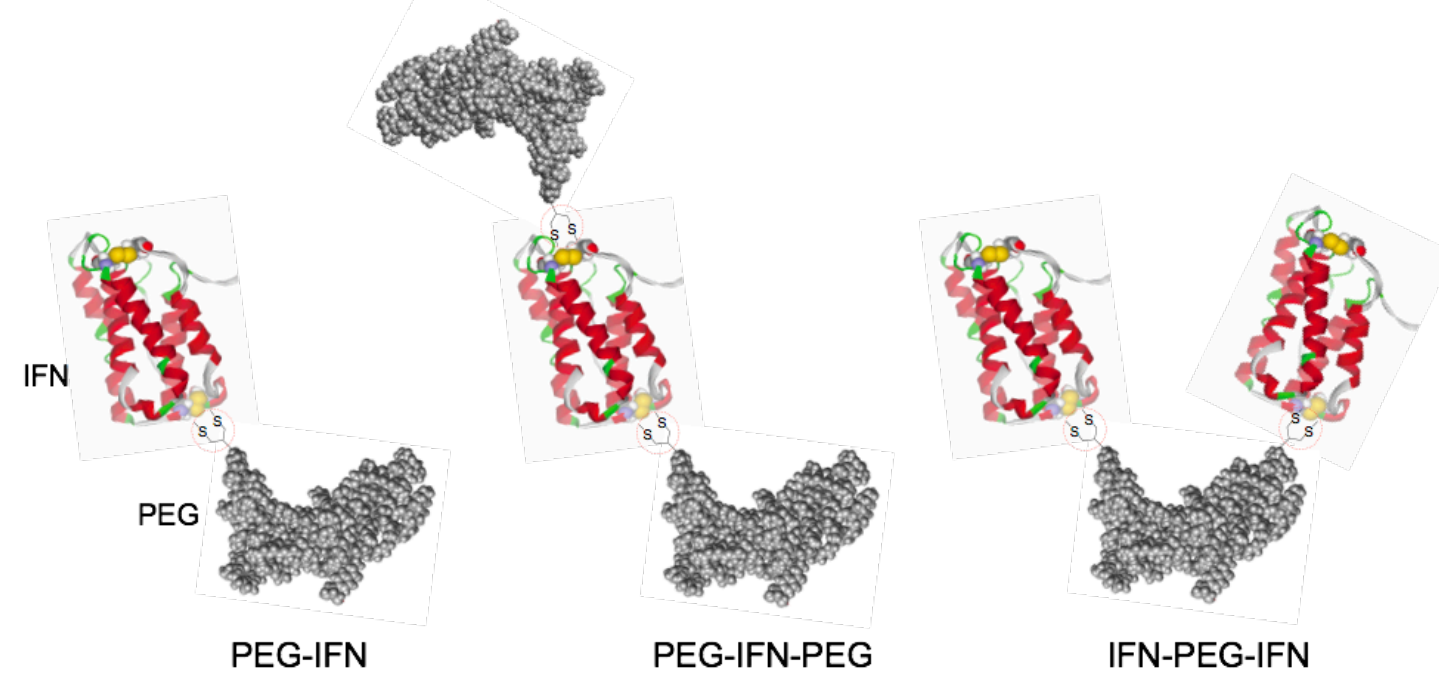

Figure 2. The range of interferon- $\alpha 2$ (IFN) conjugates that can be accomplished by disulfide re-bridging conjugation at either of the two disulfides in IFN (Cys1-98 or Cys29-Cys138). Reagents that are functionalized at each PEG terminus can be used to prepare IFN homodimers (IFN-PEG-IFN). IFN can also be prepared with a His-tag ( $\mathrm{His}_{8}$ in this study) at the Nterminus which can be site-specifically conjugated with the same reagents used for disulfide re-bridging conjugation. 


\section{Figure 3}

A

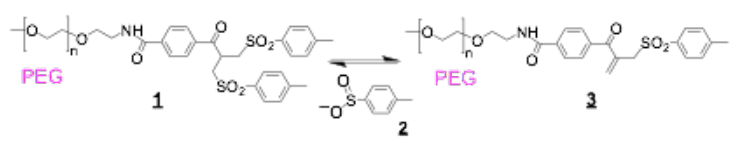

B

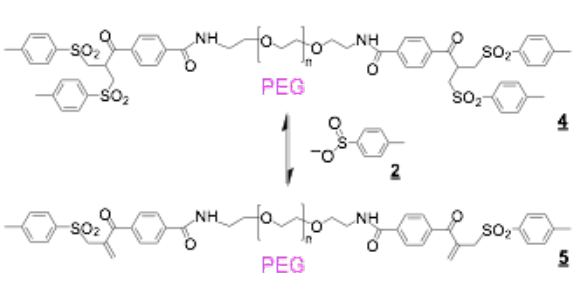

C

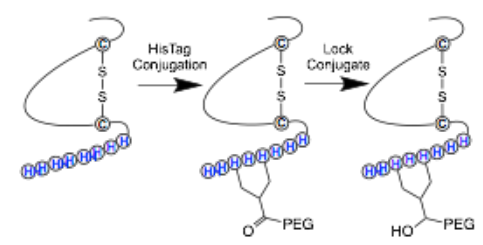

D
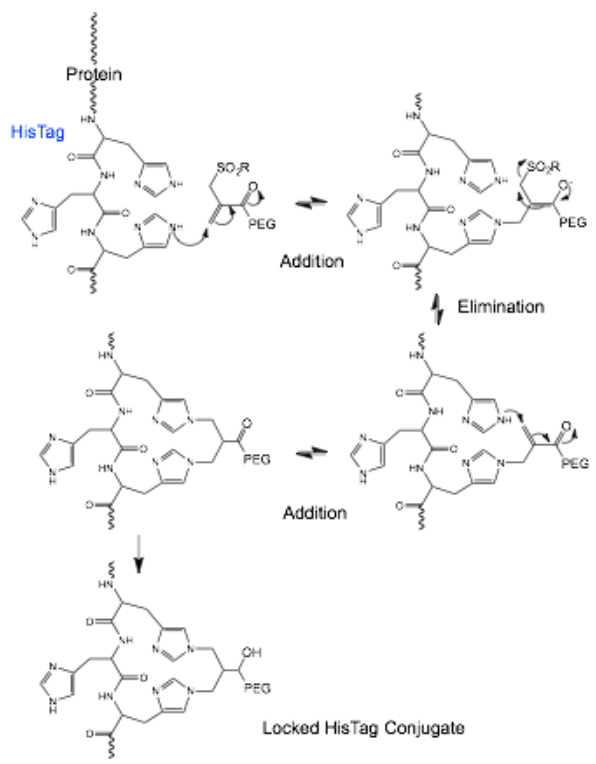

Figure 3. (A) PEG bis-sulfone 1 undergoes elimination of toluene sulfinic acid 2 leaving group to generate the PEG mono-sulfone $\mathbf{3}$ that undergoes bis-alkylation conjugation with a protein. (B) PEG linkers can be functionalized at each terminus to give the corresponding PEG di(bissulfone) $\underline{4}$ which can undergo elimination to generate the PEG di(mono-sulfone) $\underline{\mathbf{5}}$ that can undergo site-specific conjugation to two proteins. (C) A protein His-tag can also be a target for bis-alkylation conjugation. (D) Bis-alkylation conjugation to a His-tag occurs by a similar set of addition and elimination reactions, which occur for two thiols in a reduced disulfide. After conjugation, the electron-withdrawing group can be reduced to an alcohol to lock the His-tag conjugate. 


\section{Figure 4}

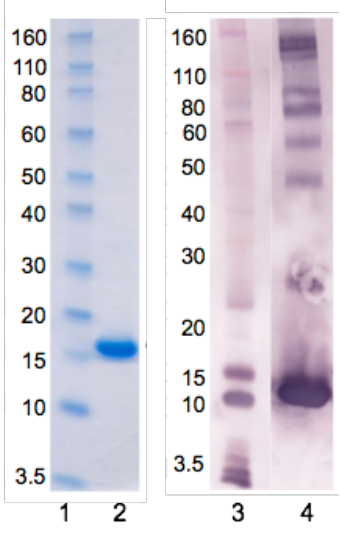

Figure 4. Characterisation of the final $\mathrm{His}_{8} \mathrm{IFN}$ product by (A) SDS-PAGE $(n=2)$ (InstantBlue ${ }^{\mathrm{TM}}$ stain), Lane 1: Novex pre-stained markers and Lane 2: purified His $\mathrm{IFN}_{8} \mathrm{FN}$ (B) Anti-IFN Western blot $(\mathrm{n}=1)$, Lane 3: protein markers and Lane 4: His 8 IFN. 


\section{Figure 5}

A

B
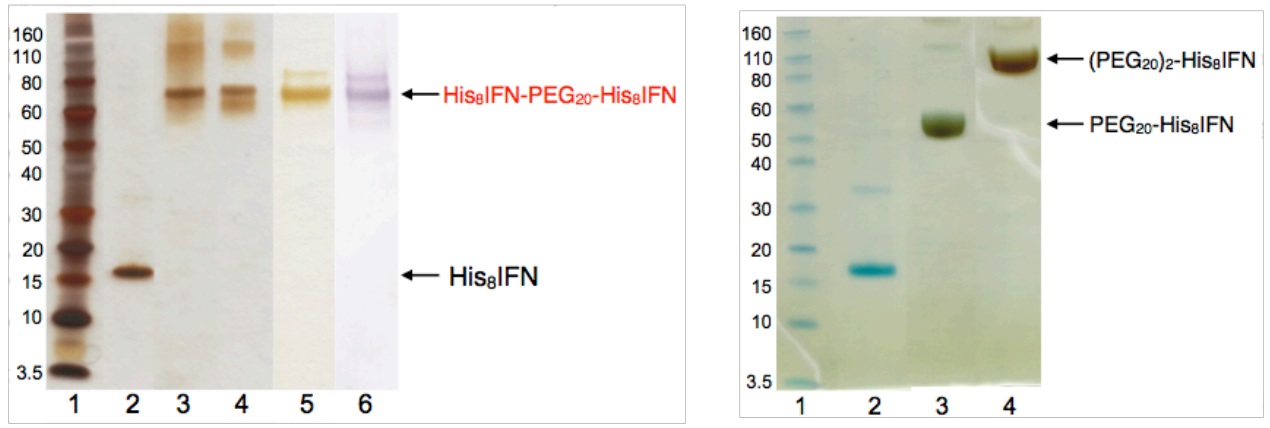

C

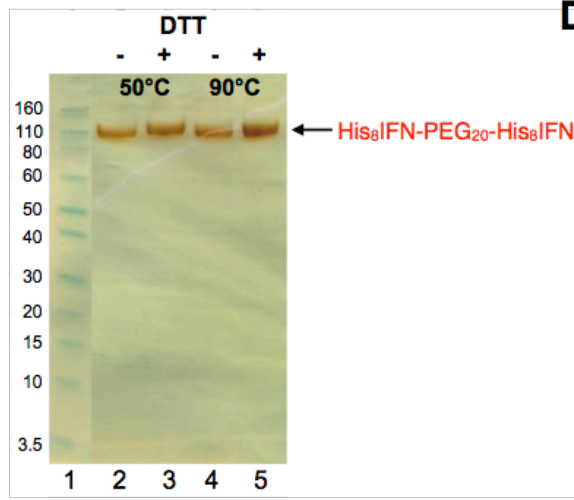

D

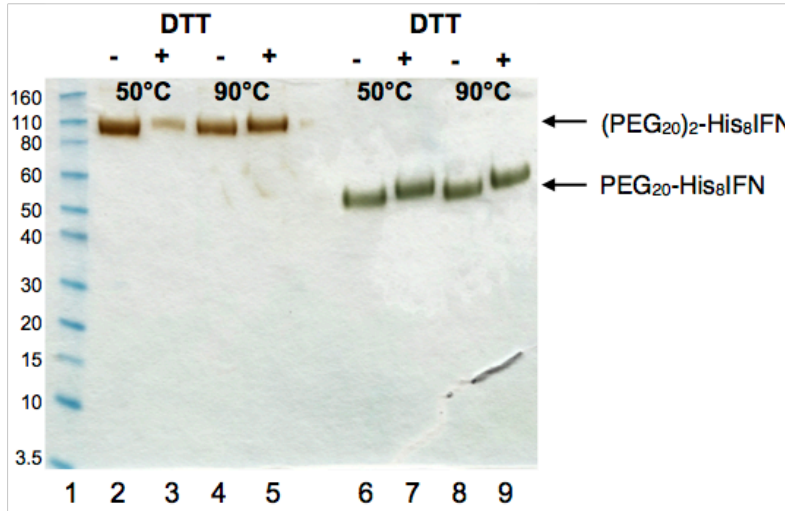

Figure 5. (A) SDS-PAGE (silver stain) of CIEX purified His ${ }_{8} I F N-P^{2} G_{20}-H i s_{8} I F N$. Lane 1: Novex pre-stained markers, Lane 2: His ${ }_{8} \mathrm{IFN}$ a-2a, Lane 3: one pass CIEX purified His 8 IFN$\mathrm{PEG}_{20}-\mathrm{His}_{8} \mathrm{IFN}$, Lane 4: two-step CIEX purified $\mathrm{His}_{8} \mathrm{IFN}-\mathrm{PEG}_{20}-\mathrm{His}{ }_{8} \mathrm{IFN}$. Lane 5: His 8 IFN$\mathrm{PEG}_{20}-\mathrm{His}_{8} \mathrm{IFN}$ after one CIEX and one SEC step and Lane 6: Anti-IFN Western blot of $\mathrm{His}_{8} \mathrm{IFN}-\mathrm{PEG}{ }_{20}-\mathrm{His}_{8} \mathrm{IFN}$. (B) SDS-PAGE (InstantBlue ${ }^{\mathrm{TM}}$ and PEG stain) of final $\mathrm{PEG}_{20}-\mathrm{His}_{8} \mathrm{IFN}$ and $\left(\mathrm{PEG}_{20}\right)_{2}-\mathrm{His}_{8} \mathrm{IFN}$, Lane 1: Novex pre-stained markers, Lane 2: His $8 \mathrm{FN}$, Lane 3: $\mathrm{PEG}_{20}{ }^{-}$ $\mathrm{His}_{8} \mathrm{IFN}$, Lane 4: $\left(\mathrm{PEG}_{20}\right)_{2}-\mathrm{His}_{8} \mathrm{IFN}$. (C) SDS-PAGE (InstantBlue ${ }^{\mathrm{TM}}$ and PEG stain) analysis of $\mathrm{His}_{8} \mathrm{IFN}-\mathrm{PEG}_{20}-\mathrm{His}_{8} \mathrm{IFN}$ homo-dimer incubated $\pm \mathrm{DTT}$ at $50^{\circ} \mathrm{C}$ and $90^{\circ} \mathrm{C}$, Lane 1: Novex prestained markers, Lane 2: -DTT $50^{\circ} \mathrm{C}$, Lane 3: +DTT $50^{\circ} \mathrm{C}$, Lane 4: -DTT $90^{\circ} \mathrm{C}$, Lane 5: +DTT $90^{\circ} \mathrm{C}$. (D) SDS-PAGE (InstantBlue ${ }^{\mathrm{TM}}$ and PEG stain) analysis of $\mathrm{PEG}_{20}-\mathrm{His}_{8} \mathrm{IFN}$ (Lanes 6-9) and $\left(\mathrm{PEG}_{20}\right)_{2}-\mathrm{His}_{8} \mathrm{IFN}$ (Lanes 2-5) stressed with $\pm \mathrm{DTT}$ at $50^{\circ} \mathrm{C}$ and $90^{\circ} \mathrm{C}$. $\mathrm{His}_{8} \mathrm{IFN}-\mathrm{PEG}_{20^{-}}$ $\mathrm{His}_{8} \mathrm{IFN}, \mathrm{PEG}_{20}-\mathrm{His}_{8} \mathrm{IFN}$ and $\left(\mathrm{PEG}_{20}\right)_{2}-\mathrm{His}_{8} \mathrm{IFN}$ were found to stable to de-conjugation. 


\section{Figure 6}

A

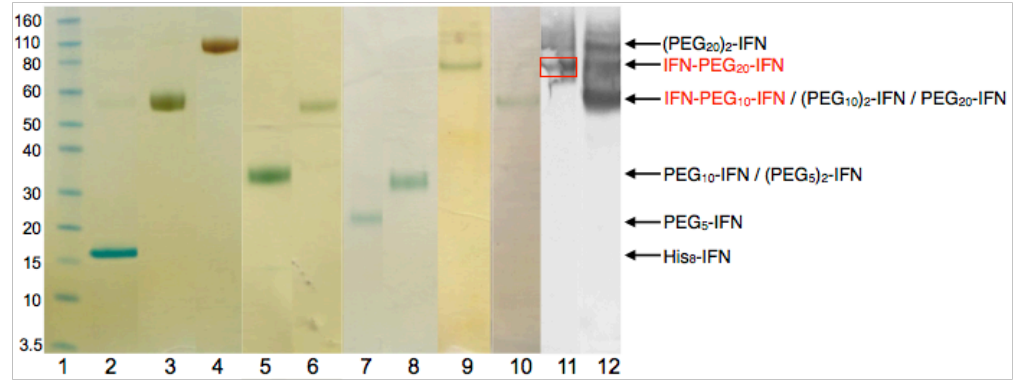

B

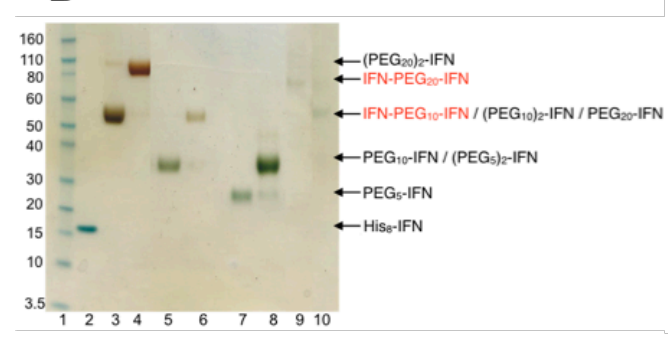

C

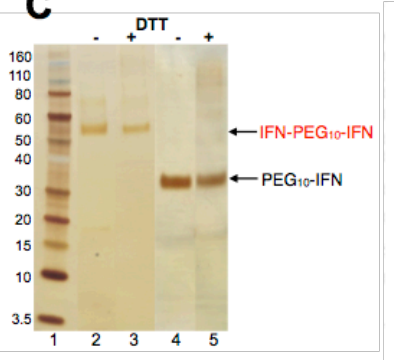

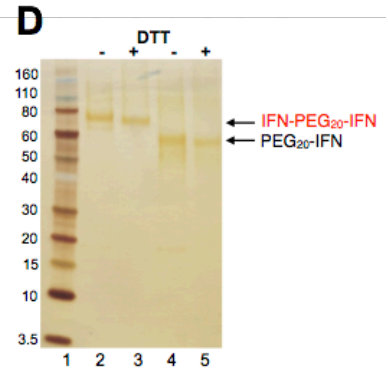

Figure 6. (A) SDS-PAGE analysis of the conjugates prepared by disulfide re-bridging conjugation of His $\mathrm{IFN}_{8}$ (InstantBlue ${ }^{\mathrm{TM}}$ and PEG stain) Lane 1: Novex pre-stained markers, Lane 2: $\mathrm{His}_{8} \mathrm{IFN}$, Lane 3: $\mathrm{PEG}_{20} \mathrm{IFN}$, Lane 4: $\left(\mathrm{PEG}_{20}\right)_{2} \mathrm{IFN}$, Lane 5: $\mathrm{PEG}_{10} \mathrm{IFN}$, Lane 6: $\left(\mathrm{PEG}_{10}\right)_{2}-\mathrm{IFN}$, Lane 7: $\mathrm{PEG}_{5} \mathrm{IFN}$, Lane 8: $\left(\mathrm{PEG}_{5}\right)_{2} \mathrm{IFN}$. Lane 9: IFN-PEG ${ }_{20}-\mathrm{IFN}$, Lane 10: IFN-PEG $10^{-} \mathrm{IFN}$, Lanes 11 and 12: Anti-IFN Western blot of IFN-PEG $20^{-I F N}$ and IFN-PEG ${ }_{10}^{-}$ IFN. (B) Thiol conjugated IFN conjugates incubated at $4^{\circ} \mathrm{C}$ for 7 days. Lane 1: Novex prestained markers, Lane 2: His 8 IFN, Lane 3: $\mathrm{PEG}_{20} \mathrm{IFN}$, Lane 4: $\left(\mathrm{PEG}_{20}\right)_{2} \mathrm{IFN}$, Lane 5: $\mathrm{PEG}_{10^{-}}$ IFN, Lane 6: $\left(\mathrm{PEG}_{10}\right)_{2}-\mathrm{IFN}$, Lane 7: $\mathrm{PEG}_{5} \mathrm{IFN}$, Lane 8: $\left(\mathrm{PEG}_{5}\right)_{2} \mathrm{IFN}$, Lane 9: IFN-PEG ${ }_{20}-\mathrm{IFN}$, Lane 10: IFN-PEG 10 -IFN. No evidence of free or aggregated protein was observed by SDSPAGE analysis using InstantBlue ${ }^{\mathrm{TM}}$ and PEG stain. (C and D) SDS-PAGE (silver stain) analysis of disulfide-conjugated IFN conjugates stressed with \pm DTT for $10 \mathrm{~min}$ at $90^{\circ} \mathrm{C}$. (C) Lane 1: Novex pre-stained markers, Lane 2: IFN-PEG 10 -IFN -DTT, Lane 3: IFN-PEG ${ }_{10}$ IFN +DTT, Lane 4: $\mathrm{PEG}_{10} \mathrm{IFN}$-DTT, Lane 5: $\mathrm{PEG}_{10} \mathrm{IFN}+\mathrm{ITT}$. (D) Lane 1: Novex pre-stained markers, Lane 2: IFN-PEG ${ }_{20}$ IFN -DTT, Lane 3: IFN-PEG ${ }_{20}$ IFN +DTT, Lane 4: $\mathrm{PEG}_{20}$ IFN DTT, Lane 5: $\mathrm{PEG}_{20} \mathrm{IFN}+\mathrm{DTT}$. The disulfide re-bridged conjugates were found to be stable to de-conjugation in DTT for $10 \mathrm{~min}$ at $90^{\circ} \mathrm{C}$. 
Figure 7

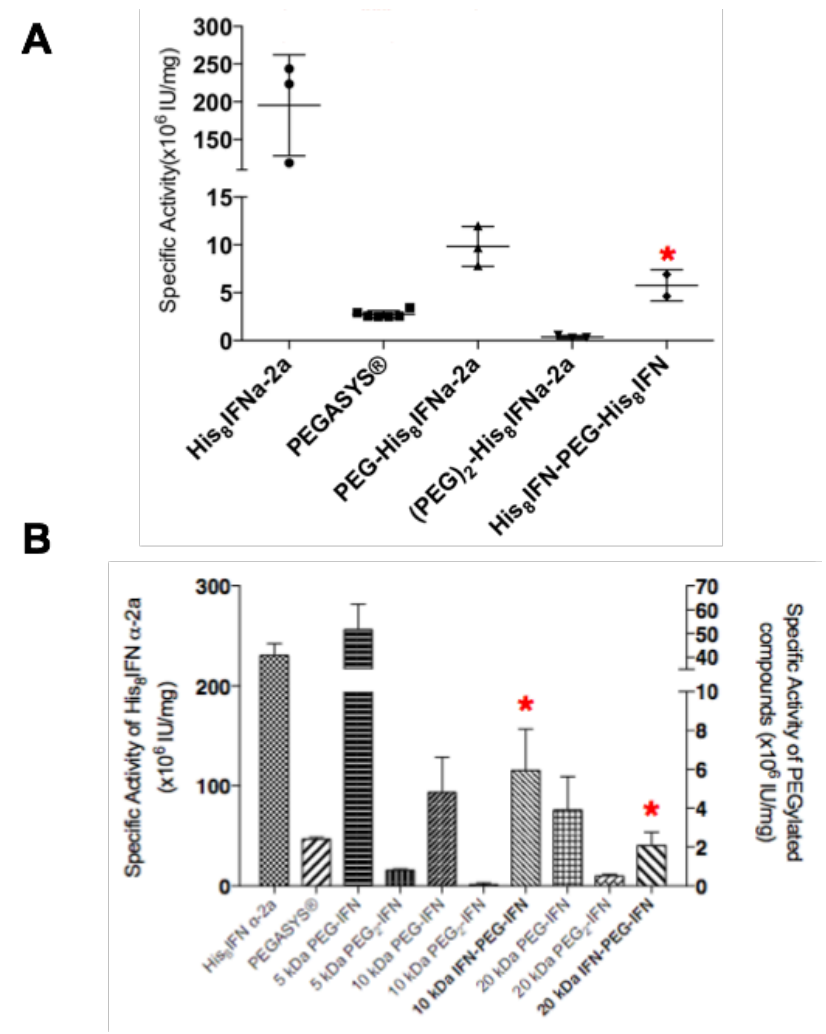

Figure 7. In vitro antiviral activity of conjugates with A549 cells incubated with EMCV virus. (A) $\mathrm{His}_{8}$-tag modified conjugate and (B) disulfide re-bridged conjugates with the left hand axis to be used for the starting His IFN $_{8}$ only. The right hand $y$-axis is used for all of the conjugates and the red stars indicate the IFN homo-dimers. 


\section{Table}

Table 1

\begin{tabular}{|c|c|c|c|c|}
\hline & Sample & Work-up & $\begin{array}{c}\text { Yield } \\
(\%)\end{array}$ & $\begin{array}{l}\text { Specific activity } \\
\text { (MIU/mg) (n) }\end{array}$ \\
\hline 1 & $\mathrm{His}_{8}$ IFN & - & - & $231.31 \pm 10.95(3)$ \\
\hline 2 & Pegasys ${ }^{(2)}$ & - & - & $2.43 \pm 0.06$ \\
\hline 3 & $\mathrm{His}_{8} \mathrm{IFN}-\mathrm{PEG}-{ }_{20}-\mathrm{His}_{8} \mathrm{IFN}$ & IEX, SEC & $1-2$ & $5.78 \pm 1.62(2)$ \\
\hline 4 & $\left(\mathrm{PEG}_{20}\right)_{2}-\mathrm{HiS}_{8} \mathrm{IFN}$ & $2 \times I E X$ & 7 & $0.38 \pm 0.16(3)$ \\
\hline 5 & $\mathrm{PEG}_{20} \mathrm{His}_{8} \mathrm{IFN}$ & $2 \times I E X$ & 18 & $9.84 \pm 2.08(3)$ \\
\hline 6 & IFN-PEG ${ }_{20}$-IFN & IEX, SEC & 1 & $2.12 \pm 0.64(4)$ \\
\hline 7 & $\mathrm{PEG}_{20}$-IFN & IEX & 29 & $3.95 \pm 1.69$ (5) \\
\hline 8 & $\left(P E G_{20}\right)_{2}-I F N$ & IEX & 12 & $0.55 \pm 0.04(3)$ \\
\hline 9 & IFN-PEG 10 -IFN & IEX, SEC & 1 & $5.99 \pm 2.08(4)$ \\
\hline 10 & $\mathrm{PEG}_{10} \mathrm{IFN}$ & IEX & 14 & $4.86 \pm 1.77(5)$ \\
\hline 11 & $\left(P E G_{10}\right)_{2}-I F N$ & IEX & 16 & $0.12 \pm 0.04(3)$ \\
\hline 12 & $\mathrm{PEG}_{5}$-IFN & IEX & 29 & $51.89 \pm 10.45(2)$ \\
\hline 13 & $\left(P E G_{5}\right)_{2}-I F N$ & IEX & 35 & $0.84 \pm 0.03(3)$ \\
\hline
\end{tabular}

Table 1. Summary of purification, yield and specific activities achieved for the IFNPEG-IFN homo-dimers (in red) and the controls that were prepared. Grey shading used to indicate the $\mathrm{His}_{8}$-tag conjugated species that were prepared. The remaining conjugates were prepared by disulfide re-bridging conjugation. 


\section{References}

1. Cordes, A. A., Platt, C. W., Carpenter, J. F.Randolph, T. W., Selective domain stabilization as a strategy to reduce fusion protein aggregation. $J$. Pharm. Sci., 2012, 101, 1400-1409.

2. Chang, C.-H., Gupta, P.Goldenberg, D. M., Advances and challenges in developing cytokine fusion proteins as improved therapeutics. Expert Opin. Drug Discov., 2009, 4, 181-194.

3. Marianayagam, N., Sunde, M.Matthews, J., The power of two: protein dimerization in biology. Trends Biochem. Sci., 2004, 29, 618-625.

4. Isaacs, A. and Lindenmann, J., Virus Interference. I. The Interferon. . Proc. R. Soc. B Biol. Sci., 1957, 147, 258-267.

5. Brassard, D., Grace, M.Bordens, R., Interferon-alpha as an immunotherapeutic protein. J. Leukoc. Biol., 2002, 71, 565-581.

6. Bell, S. J., Fam, C. M., Chlipala, E. A., Carlson, S. J., Lee, J. I., Rosendahl, M. S., Doherty, D. H.Cox, G. N., Enhanced circulating half-life and antitumor activity of a site-specific pegylated interferon-alpha protein therapeutic. Bioconjug Chem., 2008, 19, 299-305.

7. Nagabhushan, T., Reichert, P., Walter, M.Murgolo, N., Type I interferon structures: Possible scaffolds for the interferon-alpha receptor complex. Can. J. Chem., 2002, 80, 1166-1173.

8. Radhakrishnan, R., Walter, L., Hruza, A., Reichert, P., Trotta, P., Nagabhushan, T.Walter, M., Zinc mediated dimer of human interferon-alpha $2 \mathrm{~b}$ revealed by X-ray crystallography. Structure 4, 1453-1463. Structure, $1996,4,1453-1463$.

9. Nisonoff, A. and Rivers, M. M., Recombination of a mixture of univalent antibody fragments of different specificity. Arch.Biochem. Biophys., 1961, 63, 460-462.

10. Brennen, M., Preparation of Bispecific Antibodies by chemical recombinant of monoclonal immunoglobulin G1 fragments. Science, 1985, 229, 81-83.

11. Doppalapudi, V. R., Huang, J., Liu, D., Jin, P., Liu, B., Li, L., Desharnais, J., Hagen, C., Levin, N. J., Shields, M. J., Parish, M., Murphy, R. E., Del Rosario, J., Oates, B. D., Lai, J. Y., Matin, M. J., Ainekulu, Z., Bhat, A., Bradshaw, C. W., Woodnutt, G., Lerner, R. A.Lappe, R. W., Chemical generation of bispecific antibodies. Proc. Natl. Acad. Sci. U.S.A., 2010, 107, 22611-22616.

12. Xiao, J., Hamilton, B.Tolbert, T., Synthetic of N-Terminally Linked Protein and Peptide Dimers by Native Chemical Ligation. Bioconjugate Chem., 2010, 21, 1943-1947.

13. Pasche, N. and Neri, D., Immunocytokines: a novel class of potent armed antibodies. Drug Discovery Today, 2012, 17, 583-590.

14. Kontemann, R., Dual targeting strategies with bispecific antibodies. mAbs, 2012, 4, 182-197.

15. Fischer, N. and L Eacute Ger, O., Bispecific Antibodies: Molecules That Enable Novel Therapeutic Strategies. Pathobiology, 2007, 74, 3-14.

16. Schellinger, J., Kudupudi, A., Natarajan, A., Du, W., Denardo, S.GervayHague, J., A general chemical synthesis platform for crosslinking multivalent single chain variable fragments. Org. Biomol. Chem, 2012, 10, 1521-1526. 
17. Liu, R., Ji, D., Wang, J., Qui, R., Lin, Q., Zhang, G., Ma, G., Su, Z.-G.Hu, T., Preparation, characterization and in vitro bioactivity of N-terminally PEGylated staphylokinase dimers. Process Biochem., 2012, 47, 41-46.

18. Mack, E. T., Snyder, P. W., Perez-Castillejos, R.Whitesides, G. M., Using Covalent Dimers of Human Carbonic Anhydrase II To Model Bivalency in Immunoglobulins. J. Am. Chem. Soc., 2011, 133, 11701-11715.

19. Lorenzo, M., Decker, C., Kahveci, M., Paluck, S.Maynard, H., 2015. Macromolecules, 49, 30-37.

20. Mammen, M., Choi, S.Whitesides, G. M., Polyvalent interactions in biological systems: implications for design and use of multivalent ligands and inhibitors. Angew. Chem., Int. Ed., 1998, 37, 2754-2794.

21. Dalle, B., Henri, A., Rouyer-Fessard, P., Bettan, M., Scherman, D., Beuzard, Y.Payen, E., Dimeric erythropoietin fusion protein with enhanced erythropoietic activity in vitro and in vivo. Blood, 2001, 97, 3776-3782.

22. Chang, C., Rossi, E., Cardillo, T., Nordstrom, D., Mcbride, W.Goldenberg, D., A new method to produce mono-PEGylated dimeric cytokines shown with human interferon-alpha-2b. Bioconjug Chem., 2009, 20, 1899-1907.

23. Fidler, K., Jevševar, S., Milunovic, T., Skrajnar, S., Premzl, A., Kunstelj, M., Zore, I., Podobnik, B., Kusterle, M., Caserman, S., Kenig, M., Smilovic, V.Porekar, V., The characterisation and potential use of G-CSF dimers and their PEGylated conjugates. Acta Chim. Slov., 2011, 58, 1-8.

24. Balan, S., Choi , J. W., Godwin, A., Teo, I., Laborde, C. M., Heidelberger, S., Zloh, M., Shaunak, S.Brocchini, S., Site-specific PEGylation of protein disulfide bonds using a three-carbon bridge. Bioconjugate Chem., 2007, 18, 61-76.

25. Brocchini, S., Balan, S., Godwin, A., Choi, J. W., Zloh, M.Shaunaik, S., PEGylation of native disulfide bonds in proteins. Nat. Protoc., 2006, 1, 22412252.

26. Khalili, H., Khaw, P., Lever, R., Godwin, A.Brocchini, S., Fab-PEG-Fab as a potential antibody mimetic. Bioconjugate Chem., 2013, 24, 1870-1882.

27. Khalili, H., Lee, R., Khaw, P., Brocchini, S.Ad, D., An anti-TNF alpha antibody mimetic to treat ocular inflammation. Sci. Rep., 2016, 6, 36905.

28. Vauquelin, G. and Charlton, S. J., Exploring avidity: understanding the potential gains in functional affinity and target residence time of bivalent and heterobivalent ligands. Br. J. Pharmacol., 2013, 168, 1771-1785.

29. Vauquelin, G. and Charlton, S. J., Long-lasting target binding and rebinding as mechanisms to prolong in vivo drug action. Br. J. Pharmacol., 2010, 161, 488-508.

30. Khalili, H., Khaw, P.Brocchini, S., Fc-fusion mimetics. Biomater. Sci., 2016, 4, 943-947.

31. Klaus, W., Gsell, B., Labhardt, A., Wipf, B.Senn, H., The three-dimensional high resolution structure of human interferon alpha-2a determined by heteronuclear NMR spectroscopy in solution. J. Mol. Biol., 1997, 274, 661675.

32. Cong, Y., Pawlisz, E., Bryant, P., Balan, S., Laurine, E., Tommasi, R., Singh, R., Dubey, S., Peciak, K., Bird, M., Sivasankar, A., Swierkosz, J., Muroni, M., Heidelberger, S., Farys, M., Khayrzad, F., Edwards, J., Badescu, G., Hodgson, I., Heise, C., Somavarapu, S., Liddell, J., Powell, K., Zloh, M., Choi, 
J.-W., Godwin, A.Brocchini, S., Site-Specific PEGylation at Histidine Tags. Bioconjugate Chem., 2012, 23, 248-263.

33. Lobstein, J., Emrich, C., Jeans, C., Faulkner, M., Riggs, P.Berkmen, M., SHuffle, a novel Escherichia coli protein expression strain capable of correctly folding disulfide bonded proteins in its cytoplasm. . Microb. Cell Fact., 2012, $11,11$.

34. Grace, M., Lee, S., Bradshaw, S., Chapman, J., Spond, J., Cox, S., Delorenzo, M., Brassard, D., Wylie, D., Cannon-Carlson, S., Cullen, C., Indelicato, S., Voloch, M.Bordens, R., Site of Pegylation and Polyethylene Glycol Molecule Size Attenuate Interferon- $\alpha$ Antiviral and Antiproliferative Activities through the JAK/STAT Signaling Pathway. J. Biol. Chem., 2005, 280, 6327-6336.

35. Shaunak, S., Godwin, A., Choi, J. W., Balan, S., Pedone, E., Vijayarangam, D., Heidelberger, S., Teo, I., Zloh, M.Brocchini, S., Site-specific PEGylation of native disulfide bonds in therapeutic proteins. Nat. Chem. Bio., 2006, 312313.

36. Brocchini, S., Godwin, A., Balan, S., Choi, J. W., Zloh, M.Shaunak, S., Disulfide bridge based PEGylation of proteins. Adv. Drug Del. Rev., 2008, 312. 